\title{
A New Species of Kalophrynus with a Unique Male Humeral Spine from Peninsular Malaysia (Amphibia, Anura, Microhylidae)
}

\author{
$\operatorname{AUTHOR}(\mathrm{S})$ :
}

Matsui, Masafumi

\section{CITATION:}

Matsui, Masafumi. A New Species of Kalophrynus with a Unique Male Humeral Spine from Peninsular Malaysia (Amphibia, Anura, Microhylidae). Zoological Science 2009, 26(8): 579585

ISSUE DATE:

2009-08

URL:

http://hdl.handle.net/2433/216890

RIGHT:

(c) 2009 Zoological Society of Japan 


\title{
A New Species of Kalophrynus with a Unique Male Humeral Spine from Peninsular Malaysia (Amphibia, Anura, Microhylidae)
}

\author{
Masafumi Matsui* \\ Graduate School of Human and Environmental Studies, Kyoto University, \\ Sakyo-ku, Kyoto 606-8501, Japan
}

\begin{abstract}
A new microhylid, Kalophrynus yongi, is described from the Cameron Highlands of Peninsular Malaysia. Morphologically, the new species differs from all known congeners by having a very stout forelimb with a humeral spine in males. Acoustically, it resembles $K$. baluensis and $K$. heterochirus and sharply differs from $K$. interlineatus, $K$. pleurostigma, $K$. palmatissimus, and $K$. nubicola.
\end{abstract}

Key words: Kalophrynus, new species, humeral spine, Southeast Asia, tadpole, taxonomy

\section{INTRODUCTION}

The genus Kalophrynus Tschudi, 1838 is indigenous from Southern China to Java, the Philippines, and Assam, India, and includes 14 or 15 species of small litter frogs (Das and Haas, 2003; Ohler and Grosjean, 2005; Frost, 2009). It has usually been placed in the subfamily Microhylinae Mivart, 1869 (e.g., Parker, 1934), but its phylogenetic relationships with the other microhylid genera are unclear (Frost et al., 2006) and it is now considered to represent a distinct subfamily, Kalophryninae (Frost, 2009). Three species in this genus (K. pleurostigma Tschudi, 1838; K. robinsoni Smith, 1922; and K. palmatissimus Kiew, 1984) have been recorded from Peninsular Malaysia (Berry, 1975; Kiew, 1984; Das and Haas, 2003). The known localities for these species on the Peninsula are usually at relatively low elevations, and the known highest record was $1006 \mathrm{~m}$ a.s.l. for $K$. robinsoni (Parker, 1934; Dring, 1979).

During my field trips to Peninsular Malaysia, I collected specimens of a Kalophrynus species from the top of the Cameron Highlands, Pahang, nearly $2000 \mathrm{~m}$ in altitude. Herpetological surveys in the regions around the Cameron Highlands have a long history (Smedley, 1931), but recent discoveries of new species of the ranid genus Hylarana Tschudi, 1838 (Leong and Lim, 2003) and megophryid genus Leptolalax Dubois, 1980 (Matsui et al., 2009) from there suggest the inadequacy of herpetological inventories in this montane region, like the situation for the lower regions of Peninsular Malaysia, where many new species have recently been discovered (cf. Grimer and Aun, 2008).

The Kalophrynus from the Cameron Highlands is morphologically unique and clearly differs from all the known species of the genus, and is described herein as a new species.

\footnotetext{
* Corresponding author. Phone: +81-75-753-6846; Fax : +81-75-753-6846; E-mail: fumi@zoo.zool.kyoto-u.ac.jp
}

\section{MATERIALS AND METHODS}

I made frog surveys around the top of Gunung (Mt.) Brinchang, Cameron Highlands. I recorded frog calls in the field using a cassette tape recorder (Sony TC-D5) with an external microphone (Sony ECM-23) and a digital recorder (Zoom H2). At the time of recording, I measured temperature with a quick-recording thermistor thermometer (Takara A 600). Calls recorded were analyzed with the SoundEdit 2 and SoundEdit Pro (MacroMind-Paracom, Inc) software packages on a Macintosh computer, as described elsewhere (Matsui, 1997). Tissue was taken from both post-metamorphic and larval specimens for subsequent biochemical analyses. Comparison of partial mt-DNA sequences with those from several congeners established the validity of assigning metamorphs to larvae, and their distinct specific status (Matsui, unpublished data).

Post-metamorphic specimens were fixed in $10 \%$ formalin, preserved in $70 \%$ ethanol, and stored at the Graduate School of Human and Environmental Studies, Kyoto University (KUHE) and Herpetological Collection at Universiti Kebangsaan Malaysia (UKMHC). Twenty body measurements were taken mainly following Matsui (1984): 1) snout-vent length (SVL); 2) head length (HL); 3) snout length (SL); 4) snout-nostril length (S-NL); 5) nostril-eye distance (N-EL); 6) eye length (EL, including eyelid); 7) tympanum-eye length (T-EL); 8) tympanum diameter (TD); 9) head width (HW); 10) internarial distance (IND); 11) interorbital distance (IOD); 12) upper eyelid width (UEW); 13) lower arm and hand length (LAL), from elbow to tip of third finger; 14 ) forelimb length (FLL); 15) tibia length $(T L) ; 16)$ foot length (FL); 17) hindlimb length (HLL); 18) inner metatarsal tubercle length (IMTL); 19) first toe length (1TL), from distal end of inner metatarsal tubercle to tip of first toe; and 20) outer metatarsal tubercle length (OMTL). I made all measurements to the nearest $0.1 \mathrm{~mm}$ with dial calipers under a binocular dissecting microscope. I followed the system proposed by Savage (1975) for the description of toe-webbing states. Radiographs were prepared and minor dissections were made to examine the humeral spine.

For larvae fixed and preserved in $5 \%$ formalin, I took the following 13 measurements to the nearest $0.01 \mathrm{~mm}$ using a binocular dissecting microscope equipped with a micrometer: 1) total length (TOTL); 2) head-body length (HBL); 3) maximum head-body width (HBW); 4) body depth; 5) eye-snout distance; 6) eyeball diameter; 7) internarial distance; 8) interorbital distance; 9) tail length; 10) maximum tail depth; 11) maximum tail muscle depth; 12) maximum dorsal fin depth; and 13) maximum ventral fin depth. Measurements 
were made mainly following Inger (1985), and staging followed Gosner's (1960) Table.

For comparisons, I examined specimens of Kalophrynus stored at KUHE; The Natural History Museum, London (BM); Museo Civico di Storia Naturale, Genova (MSNG); and Forschungsinstitut und Naturmuseum Senckenberg, Frankfurt am Main (SMF).

\section{SYSTEMATICS}

Kalophrynus yongi sp. nov.

(Fig. 1)

\section{Diagnosis}

A medium-sized species of Kalophrynus, adult males 28.8-31.0 mm SVL (mean=30.3, $\mathrm{n}=3$ ); third toe longer than fifth; projection of fourth finger from palm as long as terminal phalanx of third finger; one or two tubercles under fourth finger; a gland above upper arm insertion; no light lateral stripe; distinct inguinal dark spot; sharp white asperities on nuptial pads; forelimb very stout, with a strongly developed humeral spine in males.

\section{Etymology}

The specific name is dedicated to Dr. Yong Hoi-Sen, Emeritus Professor of the University of Malaya, for his great contributions to Malaysian zoology.

\section{Holotype}

KUHE 15531, an adult male from near the top of Gunung Brinchang, $04^{\circ} 51^{\prime} \mathrm{N}, 101^{\circ} 38^{\prime} \mathrm{E}, 1954 \mathrm{~m}$ a.s.I., Cameron Highlands, Pahang, Peninsular Malaysia, col-

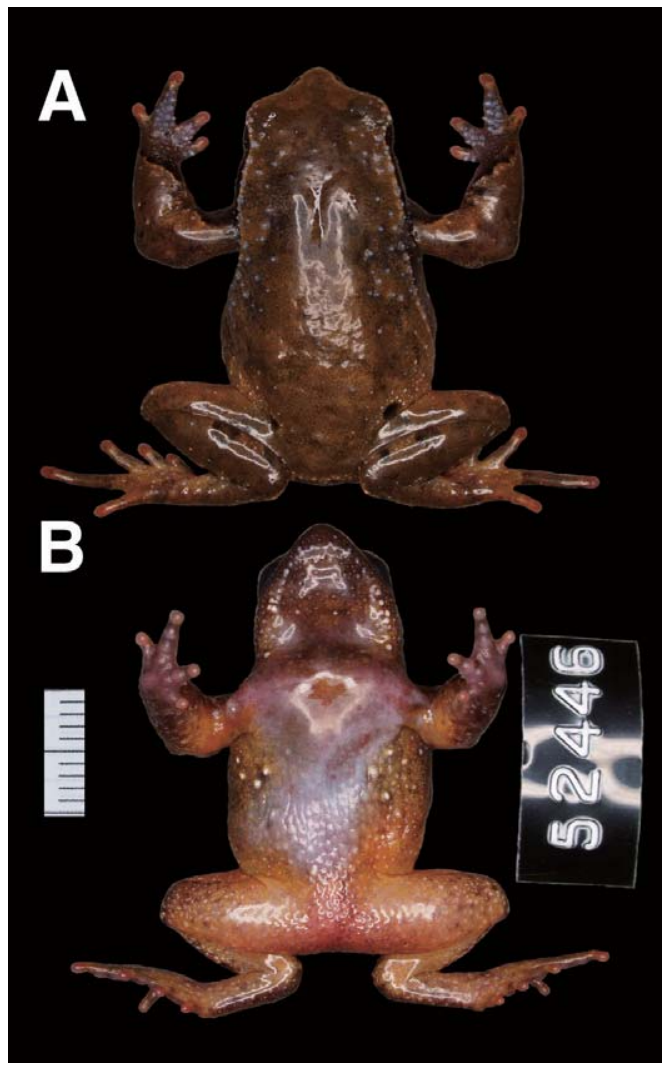

Fig. 1. (A) Dorsal and (B) ventral views of a paratype of Kalophrynus yongi (male, KUHE 52446). Scale bar, $10 \mathrm{~mm}$. lected by Kunio Araya, Masafumi Matsui, and Tsutomu Hikida on 8 January 1993.

\section{Paratypes}

UKMHC 00566, an adult male, locality and collectors as for the holotype, collected 9 January 1993; KUHE 52446, an adult male from a trail near the type locality $\left(04^{\circ} 52^{\prime} \mathrm{N}\right.$, $101^{\circ} 38^{\prime} \mathrm{E}, 1991 \mathrm{~m}$ a.s.I.), collected 11 August 2008 by Amir Hamidy, Daicus M. Belabut, Masafumi Matsui, and Kanto Nishikawa.

\section{Referred specimens}

KUHE, unnumbered: a batch of eggs and three tadpoles, locality and collectors as for the holotype; three tadpoles, from a trail near the type locality, collected 11 August 2008 by Masafumi Matsui, Amir Hamidy, Daicus M. Belabut, and Kanto Nishikawa.

\section{Description of holotype (measurements in $\mathbf{m m}$ )}

SVL 31.0; habitus stocky, body widest at sacrum; head triangular, wider (10.1) than long (9.0); snout obtusely pointed, truncate in profile, projecting slightly beyond lower jaw; eye moderate, longer (4.0) than snout (3.6); canthus rostralis distinct, straight; lore vertical, slightly concave; nostril dorsolateral, below canthus rostralis, slightly closer to tip of snout (1.4) than to eye (1.6); interorbital distance (3.5) wider than internarial distance (2.4), the latter wider than upper eyelid (2.2); pineal spot absent; tympanum distinct, diameter (2.7) more than half that of eye, and separated from eye by one-ninth of tympanic diameter (0.9); upper jaw edentate; tongue only slightly notched, without papillae; a crenulated ridge of skin on palate anterior to pharynx, preceded by a shorter, similarly strongly notched one just posterior to level of eye; a median, subgular vocal sac; small vocal openings posterior to rictus.

Forelimb long (20.8) and very stout; fingers thick, basally slightly webbed; tips rounded, not dilated; fourth finger slightly shorter than first, latter shorter than second; portion of fourth finger projecting from palm (1.2) subequal to terminal phalanx of third finger (1.1); fleshy outer palmar

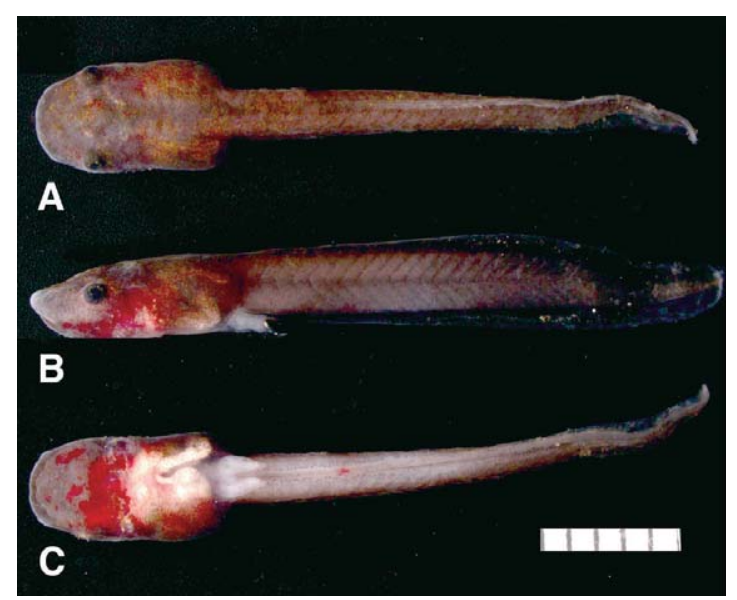

Fig. 2. (A) Dorsal, (B) lateral, and (C) ventral views of a larva of Kalophrynus yongi (Stage 32, total length=25.1 mm). Scale bar, 5 $\mathrm{mm}$. 
tubercle, inner one indistinct, subarticular tubercles rounded, numbering one on first and fourth fingers, two on second finger, three on third finger (Fig. 3A); humeral spine short, shallowly curved, not hidden below the musculature of the forearm and moderately protruding (Fig. 4).

Hindlimb moderately long (44.7); tibia not long (12.9), heels not overlapping when limbs are held at right angles to body; tibiotarsal articulation of adpressed limb reaching to the point slightly posterior to rear angle of eye; foot (13.1) subequal to tibia; toe tips rounded; third toe longer than fifth; webbing poorly developed (Fig. 3B), formula: I 2-2+ II 2-3+ III 3-4+ IV 4-2 V; subarticular tubercles prominent, rounded, numbering one on first and second toes, two on third and fifth toes, and three on fourth toe; inner metatarsal tubercle rounded, length (1.4) more than half of first toe (2.5); outer metatarsal tubercle rounded but obscure, smaller (0.6) than inner one.

Skin above very finely granular with conical tubercles scattered dorsolaterally from upper eyelid to middle of body; a gland on side of head behind tympanum, delimited by a sinuous groove from eye above and behind tympanum to axilla, and curving over insertion of arm; side of body scattered with minute tubercles; chin, abdomen, and inner side of thighs with large, flattened glandules; few large tubercles

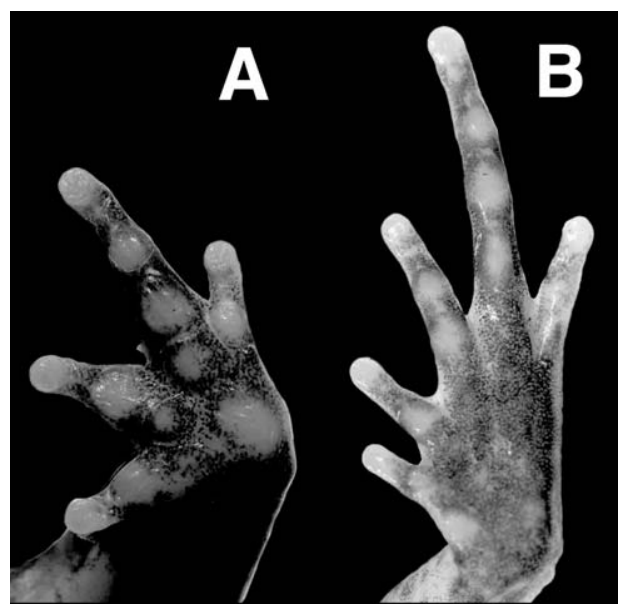

Fig. 3. Ventral views of (A) hand and (B) foot of the holotype of Kalophrynus yongi (male, KUHE 15531). Not to scale.

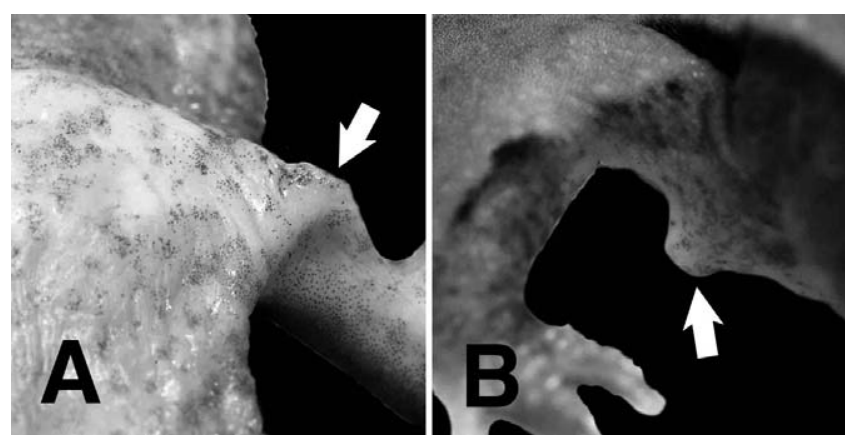

Fig. 4. (A) Ventral and (B) anterolateral views of the holotype of Kalophrynus yongi (male, KUHE 15531), showing the protruding humeral spine (arrows). Not to scale. scattered laterally on abdomen; skin of gular region not modified.; base of upper arm ventrally elevated at the position of humeral spine; inner and outer margins of fourth finger without skin fringes; nuptial pads with prominent excrescences in the form of comb-like rows of large, conical tubercles on dorsal surfaces of fingers; 10 or 12 on third finger, eight or 12 on second, and two on first.

\section{Color}

In life, ground color of dorsum highly changeable from light orange brown to dark chocolate brown, with obscure dark markings, comprising a stripe commencing from tip of snout, interorbital bar, shoulder chevron, and transverse body bars, all irregular in outline and fused with each other; sides of head and shoulder dark brown, fused with a darker line along side, from posterior corner of eye, across flank, to front of groin, and forming a boundary between lighter dorsum and darker flank; tibia dorsally with an obscure dark bar; inner sides of arms marked with dark brown; ventrum dirty cream, dusted with brown on throat and scattered with black pigmentation on limbs; conical tubercles on nuptial pad, dorsolateral tubercles, minute tubercles on flank, and large tubercles on sides of abdomen white; inguinal spot black not bordered with light marking; upper and lower halves of iris golden with black pigmentation. In preservative, color and pattern have generally faded but not obviously changed.

\section{Variation}

Individuals of the type series are generally similar in morphology. In one individual, tibiotarsal articulation of adpressed limb reaches only to rear angle of tympanum, and there are two subarticular tubercles on fourth finger.

\section{Eggs and tadpoles}

The diameter of five eggs at St. (stage of Gosner, 1960) 13 (neural plate formed) from the type locality ranged from 1.88-2.14 (mean $\pm 2 S E=1.99 \pm 0.14) \mathrm{mm}$. The animal pole was grey and the vegetal pole was cream in color.

Three tadpoles of St. 25 (TOTL=15.4 mm, HBL=3.8 mm), 30 (22.8 mm, $6.0 \mathrm{~mm})$, and 32 (25.1 mm, $7.4 \mathrm{~mm}$; Fig. 2) from near the type locality were closely examined (Table 2 ). Head-body somewhat elongate, slightly flattened above and below, HBW maximum at level of spiracle $53-55 \%$ (median $=55 \%$ ) of $\mathrm{HBL}$; depth $36-43 \%$ (median=41\%) of HBW; snout truncate; eyes lateral, visible only from above, eyeball $10-11 \%$ (median $=10 \%$ ) of $\mathrm{HBL}$; interorbital wide, $285-350 \%$ (median=318\%) of eye diameter; eye-snout distance $25-31 \%$ (median=27\%) of HBL; nostrils dorsal, but not opened in St. 25 larvae, rim not raised, midway between eye and tip of snout; internarial $43-46 \%$ (median=45\%) of interorbital.

Oral disk terminal and directed anteroventrally; width about $24 \%$ of HBW; lower lip not expanded; oral papillae, labial teeth and jaw sheaths entirely absent.

Spiracle median, without free flap, opening three-fourths of distance from tip of snout to end of body; vent median, in form of long tube directed obliquely backward, small opening at edge of ventral fin; gut in form of two, thick loops visible ventrally.

Tail long and lanceolate, tapering along posterior threefifths to bluntly rounded tip without terminal filament; tail 
Table 1. Measurements of 20 characters in Kalophrynus yongi. SVL (mean $\pm 1 S D$, in millimeters) and medians of ratios $(R)$ of other characters to SVL, followed by ranges in parenthesis. See Methods for character abbreviations.

\begin{tabular}{ccccccc}
\hline SVL & RHL & RHW & RIND & RIOD & RUEW & RSL \\
\hline $30.3+1.3$ & 29.0 & 32.6 & 7.1 & 11.3 & 7.6 & 11.5 \\
$(28.8-31.0)$ & $(28.8-29.4)$ & $(31.9-32.6)$ & $(6.9-7.7)$ & $(10.6-11.8)$ & $(7.1-7.7)$ & $(11.0-11.6)$ \\
\hline RS-NL & REL & RN-EL & RTD & RT-EL & RLAL & RFLL \\
\hline 4.5 & 13.5 & 5.6 & 8.7 & 0.6 & 48.1 & 64.6 \\
$(4.2-4.5)$ & $(12.9-13.9)$ & $(5.2-5.8)$ & $(8.7-8.7)$ & $(0.3-1.0)$ & $(47.9-49.4)$ & $(64.5-67.1)$ \\
\hline RTL & RFL & RHLL & RIMTL & R1TOEL & ROMTL & \\
\hline 41.6 & 42.3 & 144.2 & 4.7 & 7.3 & 2.4 & \\
$(38.1-43.1)$ & $(37.1-42.7)$ & $(134.5-147.6)$ & $(4.5-4.8)$ & $(6.5-8.1)$ & $(1.9-2.9)$ & \\
\hline
\end{tabular}

ended at about $1350-1650 \mathrm{hz}$ (mean $\pm S D=1531 \mathrm{hz} \pm 76, \mathrm{n}=20$ ). At least seven clear harmonics were evident.

\section{Comparisons}

In males, $K$. yongi, with a SVL of $28.8-31.0 \mathrm{~mm}$ (mean=30.3 $\mathrm{mm}$ ), is larger than $K$. robinsoni Smith, 1922 (16.8 mm [my measurement of the holotype BM 1947.2.11.51]); K. nubicola Dring, $1984 \quad(14.4-24.4 \quad \mathrm{~mm}) ; \quad K$. menglienicus Yang and Su, 1980

length $240-305 \%$ (median=280\%) of $\mathrm{HBL}$, maximum depth $12-20 \%$ (median=17\%) of length; caudal muscle moderately strong, tapering gradually; fins with sub-parallel margins, not deeper than tail muscle; dorsal fin originating at end of headbody, with a straight margin, not much deeper than ventral fin, latter about equal to depth of caudal muscle near end of tail.

Color in life brownish black on dorsum and laterally, without marking; venter grey and belly transluscent.

\section{Range}

Known only from the type locality, around the top of Gunung Brinchang, Cameron Highlands, Pahang, Peninsular Malaysia.

\section{Natural history}

On Gunung Brinchang, the breeding season of $K$. yongi seems to be long, including mid August and early January. Eggs and larvae were found in early January in a large cup of the pitcher plant Nepenthes macfarlanei Hemsl., 1905 in dense moss forests on mountain slopes. Eggs were attached to the inner wall of the cup singularly or in small clumps, above the level of water. Larvae hid themselves among debris at the bottom of the cup. Three tadpoles were collected, but I failed to fix them sufficiently for measurement. Two of them were at St. 25, though their body size greatly differed. The remaining one was already at St. 36 . The tadpoles described above were found in a hole in a stump, filled with rainwater, on partially logged slopes in mid August. They still retained much yolk (Fig. 2C) and seemed not to be feeding on other material. Males were found calling in a loose chorus at night both in January and August. Calling males hid themselves near breeding sites but were very difficult to locate. One individual vomited spiders, a grasshopper, and a weevil in the container. The only associated anuran species observed was larval Microhyla annectens Boulenger, 1900 which was found in a dumped tire filled with rainwater.

\section{Call characteristics}

Calls (Fig. 5) were recorded at an air temperature of $13.1-14.5^{\circ} \mathrm{C}$. The call was a soft 'ting', and emitted intermittently with a note gap of 3.3-7.0 s (mean $\pm S D=4.41 \mathrm{~s} \pm 1.08$, $\mathrm{n}=12$ ). It consisted of a short, unpulsed note and lasted about 134-288 ms (mean $\pm S D=174.7 \mathrm{~ms} \pm 37.5, \mathrm{n}=21$ ). The dominant frequency was the fundamental, and slight frequency modulation was present. The initial frequency of $1300-1600 \mathrm{hz}($ mean $\pm S D=1532 \mathrm{hz} \pm 80, \mathrm{n}=20)$ quickly rose to $1300-1800 \mathrm{hz}$ (mean $\pm S D=1566 \pm 363 \mathrm{hz}, \mathrm{n}=19)$, and
(19.8-23.4 mm, mean=21.2 mm); K. bunguranus (Günther, 1895) $(20.7-22.8 \mathrm{~mm}$, mean $=21.8 \mathrm{~mm}$ [my measurement of the syntypes BM 1974.4061, 4065, 4066]); K. subterrestris Inger, $1966(21.0-23.4 \mathrm{~mm}$, mean=22.6 mm); K. heterochirus Boulenger, $1900(24.1-27.2 \mathrm{~mm}$, mean=26.3 mm); $\mathrm{K}$. eok Das and Haas, $2003(26.3 \mathrm{~mm})$; and $K$. punctatus Peters, 1871 (28.3 mm [my measurement of the holotype MSNG 29130]). By contrast, the remaining species are larger than $K$. yongi in male body size: $K$. minusculus Iskandar, 1998 (32.2 mm [my measurement of SMF 53814]); $K$. palmatissimus $(31.2-38.8 \mathrm{~mm}, \quad$ mean $=34.5 \mathrm{~mm}) ; \mathrm{K}$. orangensis Dutta, Ahmed, and Das, 2000 (35-38 mm); K. intermedius Inger, 1966 (37.9-40.5 mm, mean=39.2 mm); K. baluensis Kiew, 1984 (34.8-39.0 mm); K. pleurostigma (35.0-50.4 mm, mean=42.2 mm); and $K$. interlineatus Blyth, 1855 (37.4-47.7 mm) (data from Das and Haas, 2003; Dring, 1979, 1984; Inger, 1954, 1966; Iskandar, 1998; Kiew, 1984a, b; Matsui, 1979, unpublished; Yang and Su, 1980).

Most remarkably, $K$. yongi differs from all the other Kalophrynus species in having strongly developed terminal ridges on humerus, and related skin modification. In addition, it differs from the other Kalophrynus species in the following characteristics (data from Das and Haas, 2003; Dring, 1984; Inger, 1966; Kiew, 1984a,b; Matsui et al., 1996, unpublished; Mertens, 1957; Yang and Su, 1980): (1) subarticular tubercles of fingers and toes distinct (indistinct or absent in K. nubicola); (2) fifth toe not projecting as far as third toe (projecting as far as or farther than third in $K$. punctatus); (3) tympanum distinct and toe web present (tympanum concealed and no toe web in K. menglienicus); (4)

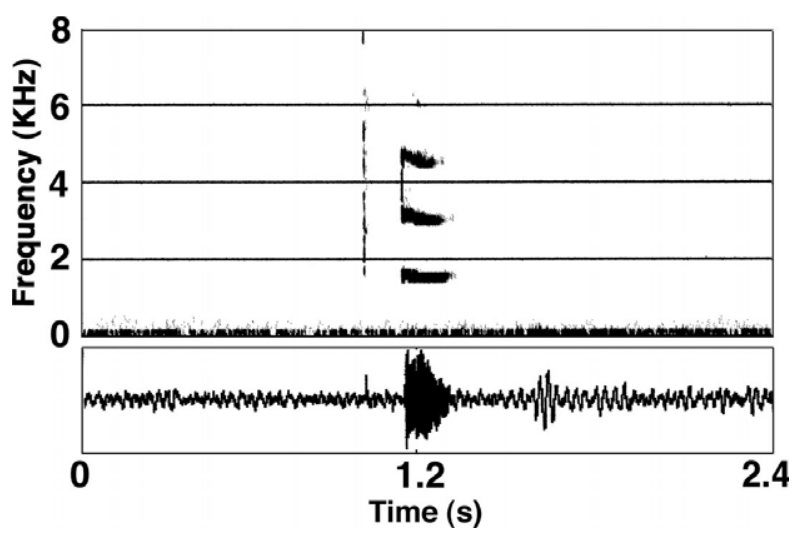

Fig. 5. Sonagram of an advertisement call of Kalophrynus yongi. 
second finger with two subarticular tubercles (single subarticular tubercle in K. eok); (5) fifth toe with two subarticular tubercles (no subarticular tubercle in $K$. subterrestris and $K$. intermedius); (6) portion of fourth finger projecting from palm as long as terminal phalanx of third finger (longer than terminal phalanx of third finger in $K$. interlineatus, $K$. minusculus, $K$. palmatissimus, $K$. pleurostigma, and $K$. orangensis); (7) no light stripe or line on snout or side (a light stripe or line along canthus rostralis, extending back along side almost to groin in $K$. bunguranus [Leong et al., 2003] and K. heterochirus); and (8) distinct spines on male nuptial pad (without spines in $K$. baluensis). In addition, $K$. palmatissimus has well-developed webbing on fourth toe to beyond median subarticular tubercle, which sharply contrasts with the poorly developed webbing in $K$. yongi.

In the larvae, $K$. yongi differs from $K$. pleurostigma from Singapore reported by Leong and Chou (1999) (=smaller form of K. p. pleurostigma from Peninsular Malaysia of Berry, 1972) in having larger body size $(7.4 \mathrm{~mm}$ in $\mathrm{HBL}$ at St. 32 vs. to $4.3 \mathrm{~mm}$ at St. 43 in K. pleurostigma), an elongate head-body (vs. subspherical in $K$. pleurostigma) with dorsolateral eyes not visible from below (vs. lateral eyes visible from above and below in $K$. pleurostigma), and tail fins lower than tail muscle and ventral and dorsal fins similar in depth (vs. fins deeper than tail muscle after proximal third and ventral twice depth of dorsal in anterior quarter of tail in $K$. pleurostigma). Larval $K$. yongi also differs from Berry's (1972) larger form of K. p. pleurostigma from Peninsular Malaysia in having larger body size (to $4.5 \mathrm{~mm}$ at St. 36 in the larger form), and in having a rounded tail and terminal mouth (vs. an acutely pointed tail and a ventrolateral mouth in the larger form). Kiew (1984a) described larval $K$. palmatissimus from Malaysia as having the head-body 8 $\mathrm{mm}$ in length at St. 38 and rounded ventrally, eye visible from below, slightly extended lips, spiracle with a free flap of skin, longitudinal grooves on ventral surface of abdomen, tail fins as high as muscle at middle of tail, filamentous tail tip, and weak caudal muscle, all of which differ from the characteristics of $K$. yongi.

Calls have been analyzed for four species of Kalophrynus (K. nubicola from Borneo by Dring [1984]; K. pleurostigma from Borneo by Matsui et al. [1996]; $K$. interlineatus from Thailand by Matsui et al. [1996] and from Vietnam by Ohler and Grosjean [2005]; and K. baluensis from Borneo by Malkmus and Riede [1996]). Calls of $K$. nubicola described by Dring (1984) were expressed as 'gek' (type-one call) or 'gegger' (type-two call). Of these, type one is more similar to the call of $K$. yongi in duration. However, calls of $K$. nubicola were reported to be well pulsed, unlike the unpulsed calls of $K$. yongi. The call of $K$. pleurostigma is composed of successive notes (Matsui et al., 1996) and that of $K$. interlineatus is a long trill (Matsui et al., 1996; Ohler and Grosjean, 2005), unlike the short note in $K$. yongi. By contrast, the call of $K$. baluensis is similar to that of $K$. yongi to the human ear (Matsui, unpublished). The call characteristics of this species recorded at $19.0^{\circ} \mathrm{C}$ (Malkmus and Riede, 1996) are basically similar to those of $K$. yongi. However, the reported dominant frequency of $K$. baluensis, $2600 \mathrm{hz}$, is decidedly higher than that of $K$. yongi (mean=1531 hz), despite the former having larger body size than the latter (see above). The difference is not ascribed to different temperatures at the time of record- ing (13.1-14.5 $5^{\circ} \mathrm{C}$ in $K$. yongi), either, and should be regarded as a specific one. Although not yet analyzed in detail, the call of $K$. yongi resembles that of $K$. heterochirus from Borneo, but sharply differs from that of $K$. palmatissimus from the Peninsula (Matsui, unpublished). The call of $K$. palmatissimus has been described as a soft "ko-ko-ko-ko" (Kiew, 1984), and is clearly very different from that of $K$. yongi.

\section{DISCUSSION}

Peninsular Malaysia forms a central geographical link between the faunas of Indochina and the Sunda Islands. Herpetological studies in this region have a long history (e.g., Boulenger, 1887, 1912a; Flower, 1896; Laidlaw, 1900; Butler, 1904; Smith, 1922, 1930), but for much of the latter half of the last century, studies were less frequent and sporadic (e.g., Grandison, 1972; Dring, 1979; Kiew, 1987) than in the eastern part (Sabah and Sarawak of Borneo) (e.g., Dring, 1984, 1987; Inger, 1956, 1964, 1966; Inger and Tang, 1996; Matsui, 1979, 1986).

Recent herpetofaunal surveys have greatly clarified the high amphibian diversity on the Peninsula (e.g., Leong et al., 2003; Grismer, 2006a,b, 2007; McLeod and Norhayati, 2007). Some species formerly treated as wide ranging were separated as distinct forms: Hylarana banjarana (Leong and Lim, 2003) from H. signata (Günther, 1872) (Leong and Lim, 2003); Ansonia latirostra Grismer, 2006 and $A$. jeetsukumarani Wood, Grismer, Norhayati and Juliana, 2008 from A. malayana Inger, 1960; A latiffi Wood, Grismer, Norhayati and Juliana, 2008 from A. leptopus (Günther, 1872) (Grismer, 2006b; Wood et al., 2008); and Microhyla mantheyi Das, Yaakob, and Sukumaran, 2007 from M. borneensis Parker, 1928 (Das et al., 2007).

Nevertheless, inventory studies remain insufficient and there are still many regions to be explored in detail. The discovery of $K$. yongi represents such a case, as did a new Leptolalax recently described from the same highlands (Matsui et al., 2009). Because the morphological and acoustic characteristics of $K$. yongi are so unique, it should not have been confused with congeneric species if herpetologists had ever encountered it. Even so, the possibility of the actual range of $K$. yongi extending to other mountain ranges on the Peninsula, such as Fraser's Hill or Gunong Tahan, is not precluded, although the range is probably not so wide because of limited habitat at higher elevations. Further field surveys are badly needed to understand the pattern of distribution and to infer the evolutionary history of the genus Kalophrynus.

Kalophrynus yongi is characterized by having a humeral spine in the male. This bony spine on the upper part of each forelimb is the ventrolateral extensions of the humeral crista ventralis (Noble, 1924; Ruiz-Carranza and Lynch, 1991). The spine has been reported in males of various frog lineages, e.g., in Centrolenidae Taylor, 1951 (Centrolene Jiménez de la Espada, 1872) (Cisneros-Heredia and Mcdiarmid, 2007); in Ceratophryidae Tschudi, 1838 (Telmatobius Wiegmann, 1834) (Parker, 1940; De la Riva, 1994; Lavilla and Ergueta, 1999); in Hylidae Rafinesque, 1815 (Bokermannohyla Faivovich, Haddad, Garcia, Frost, Campbell, and Wheeler, 2005 [Bokermann, 1964], Ecnomiohyla Faivovich, Haddad, Garcia, Frost, Campbell, and Wheeler, 2005 [Mendelson et al., 2008], and Litoria Tschudi, 1838 [Boulenger, 1912b; Zweifel, 1958; Faivovich et al., 2005]); and in Rhacophoridae Hoffman, 1932 
(Philautus Gistel, 1848) (Kuramoto and Joshy, 2003). However, no spine has been reported in the genus Kalophryus or in the family Microhylidae Günther, 1858.

Cisneros-Heredia and Mcdiarmid (2007) recognized considerable variation in the degree of development of the humeral spine among species of Centrolene, and the nonprotruding spine found in $K$. yongi is poorly developed. Although Cisneros-Heredia and Mcdiarmid (2007) considered the spine to be a synapomorphy for Centrolene, not all species other genera of Centrolenidae have the spine. I regard the unique humeral spine in $K$. yongi as an apomorphic character state within the genus and an autapomorphy for the species. Although the humeral spine in male $K$. yongi is of unknown function, it may be advantageous for maintaining amplexus, as suggested by the massive forelimb and strongly developed nuptial spines, and field observations of the breeding behavior are necessary.

Members of Kalophrynus have been reported to breed in shallow, temporary rain pools, rain-filled road ruts, waterfilled holes in logs, decaying bamboo internodes, burrows in stream banks, and pitcher plant cups (e.g., Inger, 1966; Leong and Chou, 1999). Although Inger (1966) assigned a nepenthiphillous larva from Borneo to Kalophrynus, the generic identification remained questionable. Lim and $\mathrm{Ng}$ (1991) first confirmed the use of pitcher plant cups for breeding sites in this genus, in $K$. pleurostigma from Singapore. As these authors suggested, nepenthiphilous habits of Kalophrynus would be an extension of the phytotelmic breeding preference, and large pitchers of Nepenthes should be an especially important breeding place for $K$. yongi on steep slopes at the tops of high mountains, where rainwater scarcely remains. Leong and Chou (1999) reported that $K$. pleurostigma in Singapore uses Nepenthes ampullaria Jack, 1835, whose cups are smaller than those of $N$. macfarlanei used by $K$. yongi, and this difference in the size of the breeding pot may be related to the difference in larval body size between the two species.

\section{ACKNOWLEDGMENTS}

I am grateful to H.-S. Yong for continuously helping conduct research in Malaysia. Permission to conduct fieldwork in Peninsular Malaysia between 1992 and 1993 was provided by the SocioEconomic Research Unit of Malaysia. The field trip to the Peninsula in 2008 was made under research permit 40/200/19/2285 from the Economic Planning Unit, Prime Minister's Department. I thank T. Hikida, H. Ota, K. Araya, B. Daicus, A. Norhayati, K. Nishikawa, A. Hamidy, and H. B. Mdshah for help in fieldwork; C. McCarthy and B. T. Clarke (BM), G. Doria (MSNG), and G. Köhler (SMF) for allowing me to examine specimens under their care; and T.-M. Leong and an anonymous reviewer for improving an earlier version of this manuscript. This study was supported by grants from The Monbusho International Scientific Research Program (Field Research, 04041068, 10041166), The Monbusho through the Japanese Society for the Promotion of Sciences (JSPS: Field Research, 20405013), and Universiti Kebangsaan Malaysia (UKM-OUP-PLW-14-59/2008).

\section{REFERENCES}

Berry PY (1972) Undescribed and little known tadpoles from West Malaysia. Herpetologica 28: 338-346

Berry PY (1975) The Amphibian Fauna of Peninsular Malaysia. Tropical Press, Kuala Lumpur

Bokermann WCA (1964) Dos nuevas especies de Hyla de Minas Gerais y notas sobre Hyla alvarengai Bok (Amphibia, Salientia,
Hylidae). Neotropica 10: 67-76

Boulenger GA (1887) On new batrachians from Malacca. Ann Mag Nat Hist 5 19: 345-348

Boulenger GA (1912a) A Vertebrate Fauna of Malay Peninsula from the Isthmus of Kra to Singapore Including Adjacent Islands. Taylor and Francis, London

Boulenger GA (1912b) On some tree-frogs allied to Hyla caerulea with remarks on noteworthy secondary sexual characters in the family Hylidae. Zool Jahrb 1 15: 211-218

Butler AL (1904) A list of the batrachians known to inhabit the Malay Peninsula, with some remarks on their habits, distribution, etc. $J$ Bombay Nat Hist Soc 15: 193-205, 387-402

Cisneros-Heredia DF, Mcdiarmid RW (2007) Revision of the characters of Centrolenidae (Amphibia: Anura: Athesphatanura), with comments on its taxonomy and the description of new taxa of glassfrogs. Zootaxa 1572: 3-82

Das I, Haas A (2003) A new species of Kalophrynus (Anura: Microhylidae) from Central Borneo. Raffles Bull Zool 51: 113-117

Das I, Norsham Y, Sukumaran J (2007) New species of Microhyla (Anura: Microhylidae) from the Malay Peninsula. Hamadryad 31: $306-315$

De La Riva I (1994) A new aquatic frog of the genus Telmatobius (Anura: Leptodactylidae) from Bolivian cloud forests. Herpetologica 50: $38-45$

Dring JCM (1979) Amphibians and reptiles from northern Trengganu, Malaysia, with descriptions of two new geckos: Cnemaspis and Cyrtodactylus. Bull Br Mus Nat Hist (Zool) 34: 181-241

Dring JCM (1984 "1983") Some new frogs from Sarawak. AmphibiaReptilia 4: 103-115

Dring JCM (1987) Bornean treefrogs of the genus Philautus (Rhacophoridae). Amphibia-Reptilia 8: 19-47

Faivovich J, Haddad CFB, Garcia PCA, Frost DR, Campbell JA, Wheeler WC (2005) Systematic review of the frog family Hylidae, with special reference to Hylinae: a phylogenetic analysis and taxonomic revision. Bull Am Mus Nat Hist 294: 1-240

Flower SS (1896) Notes on a second collection of batrachians made in the Malay Peninsula 1895-96, with a list of the species recorded from that region. Proc Zool Soc Lond 1896: 856-914

Frost DR (2009) Amphibian species of the world: an online reference. Version 5.3 (12 February, 2009). American Museum of Natural History, New York, Electronic database accessible at http://research.amnh.org/herpetology/amphibia/index.html

Frost DR, Grant T, Faivovich J, Bain RH, Haas A, et al. (2006) The amphibian tree of life. Bull Am Mus Nat Hist 297: 1-370

Gosner KL (1960) A simplified table for staging anuran embryos and larvae with notes on identification. Herpetologica 16: 183-190

Grandison AGC (1972) The Gunong Benom Expedition 1967. 5. Reptiles and amphibians of Gunong Benom with a description of a new species of Macrocalamus. Bull Br Mus Nat Hist (Zool) 23: $45-101$

Grismer LL (2006a) A new species of Ansonia Stoliczka 1872 (Anura: Bufonidae) from a lowland rainforest in southern Peninsular Malaysia. Herpetologica 62: 466-475

Grismer LL (2006b) A new species of Ansonia Stoliczka 1872 (Anura: Bufonidae) from central Peninsular Malaysia and a revised taxonomy for Ansonia from the Malay Peninsula. Zootaxa 1327: 1-21

Grismer LL (2007) A new species of Ingerophrynus (Anura: Bufonidae) from a lowland rainforest in southern Peninsular Malaysia. J Herpetol 41: 225-230

Grimer LL, Aun PK (2008) Diversity, endemism, and conservation of the amphibians and reptiles of southern Peninsular Malaysia and its offshore Islands. Herpetol Rev 39: 270-281

Inger RF (1954) Systematics and zoogeography of Philippine Amphibia. Fieldiana Zool 33: 181-531

Inger RF (1956) Some amphibians from the lowlands of North Borneo. Fieldiana Zool 34: 389-424 
Inger RF (1964) Two new species of frogs from Borneo. Fieldiana Zool 44: 151-159

Inger RF (1966) The systematics and zoogeography of the Amphibia of Borneo. Fieldiana Zool 52: 1-402

Inger RF (1985) Tadpoles of the forested regions of Borneo. FieIdiana Zool New Ser 26: v + 1-89

Inger RF, Tan FL (1996) Checklist of the frogs of Borneo. Raffles Bull Zool 44: 551-574

Iskandar DT (1998) The Amphiibians of Java and Bali. Puslitbang Biologi, LIPI, Bogor

Kiew BH (1984a) A new species of sticky frog (Kalophrynus palmatissimus n. sp.) from Peninsular Malaysia. Malay Nat $\mathrm{J}$ 37: $145-152$

Kiew BH (1984b) A new species of frog (Kalophrynus baluensis $n$. sp.) from Mount Kinabalu, Sabah, Malaysia. Malay Nat J 38: $151-156$

Kiew BH (1987) An annotated checklist of the herpetofauna of Ulu Endau, Johore, Malaysia. Malay Nat J 41: 413-423

Kuramoto M, Joshy SH (2003) Two new species of the genus Philautus (Anura: Rhacophoridae) from the Western Ghats, southwestern India. Cur Herpetol 22: 51-60

Laidlaw FF (1900) On the frogs collected during the "Skeat Expedition" to the Malay Peninsula, 1899-1900. Proc Zool Soc Lond 1900: 883-890

Lavilla EO, Ergueta SP (1999) A new Bolivian species of the genus Telmatobius (Anura: Leptodactylidae) with a humeral spine. Amphibia-Reptilia 20: 55-64

Leong TM, Chou LM (1999) Larval diversity and development in the Singapore Anura (Amphibia). Raffles Bull Zool 47: 81-137

Leong TM, Lim BL (2003) A new species of Rana (Amphibia: Anura: Ranidae) from the highlands of the Malay Peninsula, with diagnostic larval descriptions. Raffles Bull Zool 51: 115-122

Leong TM, Grismer LL, Mumpuni (2003) Preliminary checklists of the herpetofauna of the Anambas and Natuna Islands (South China Sea). Hamadryad 27: 165-174

Leong TM, Matsui M, Yong HS, Hamid AA (2003) Revalidation of Rana latelimaculata Barbour et Noble, 1916 from synonymy of Rana baramica Boettger, 1901. Cur Herpetol 22: 17-27

Lim KKP, Ng PKL (1991) Nepenthiphilous larvae and breeding habits of the sticky frog, Kalophrynus pleurostigma Tschudi (Amphibia: Microhylidae). Raffles Bull Zool 39: 209-214

Malkmus R, Riede K (1996) Zur Bioakustik von Megophrys baluensis (Boulenger,1899) und Kalophrynus baluensis Kiew, 1984, zweier seltener Froscharten aus Borneo (Anura: Pelobatidae, Microhylidae). Herpetozoa 9: 151-155

Matsui M (1979) Amphibians from Sabah. I. Systematic and natural history notes. Contrib Biol Lab Kyoto Univ 25: 303-346

Matsui M (1984) Morphometric variation analyses and revision of the Japanese toads (genus Bufo, Bufonidae). Contrib Biol Lab Kyoto Univ 26: 209-428

Matsui M (1986) Three new species of Amolops from Borneo (Amphibia, Anura, Ranidae). Copeia 1986: 623-630

Matsui M (1997) Call characteristics of Malaysian Leptolalax with a description of two new species (Anura: Pelobatidae). Copeia 1997: 158-165
Matsui M, Chan-ard T, Nabhitabhata J (1996) Distinct specific status of Kalophrynus pleurostigma interlineatus (Anura, Microhylidae). Copeia 1996: 440-445

Matsui M, Daicus MB, Norhayati A, Yong HS (2009) A new species of Leptolalax (Amphibia, Anura, Megophryidae) from Peninsular Malaysia. Zool Sci 26: 243-247

McLeod DS, Norhayati A (2007) A new species of Theloderma (Anura: Rhacophoridae) from southern Thailand and Peninsular Malaysia. Rus J Herpetol 14: 65-72

Mendelson III JR, Savage JM, Griffith E, Ross H, Kubicki B, Gagliardo R (2008) Spectacular new gliding species of Ecnomiohyla (Anura: Hylidae) from Central Panama. J Herpetol 42: $750-759$

Mertens R (1957) Amphibien und Reptilien aus dem aussersten westen Javas und von benachbarten Eilenden. Treubia 24: 83105

Noble GK (1924) Some Neotropical batrachians preserved in the United States National Museum with a note on the secondary sexual characters of these and other amphibians. Proc Biol Soc Wash 37: 65-72

Ohler A, Grosjean S (2005) Color pattern and call variation in Kalophrynus from south-east Asia (Anura: Microhylidae). Herpetozoa 18: 99-106

Parker HW (1934) A Monograph of the Frogs of the Family Microhylidae. Jarrold and Sons, London

Parker HW (1940) The Percy Sladen Trust expedition to Lake Titicaca in 1937. XII. Amphibia. Trans Linn Soc Lond 1: 203216

Ruiz-Carranza PM, Lynch JD (1991) Ranas Centrolenidae de Colombia I. Propuesta de una nueva clasificación genérica. Lozania 57: 1-30

Savage JM (1975) Systematics and distribution of the Mexican and Central American stream frogs related to Eleutherodactylus rugulosus. Copeia 1975: 254-306

Smedley N (1931) Amphibians and reptiles from the Cameron Highlands, Malay Peninsula. Bull Raffles Mus 6: 105-123

Smith MA (1922) On a collection of reptiles and batrachians from the mountains of Pahang, Malay Peninsula. J Fed Malay Stat Mus 10: 263-282

Smith MA (1930) The reptilia and amphibia of the Malay Peninsula from the Isthmus of Kra to Singapore including the islands. Bull Raffles Mus 3: 1-149

Wood PL JR, Grismer LL, Norhayati A, Juliana S (2008) Two new species of torrent-dwelling toads Ansonia Stoliczka, 1870 (Anura: Bufonidae) from Peninsular Malaysia. Herpetologica 64: $321-334$

Yang DT, Su CY (1980) A new species of the family Microhylidae frog from Yunnan. Zool Res 1: 257-260

Zweifel RG (1958) Results of the Archbold Expeditions. No. 78. Frogs of the Papuan hylid genus Nyctimystes. Am Mus Novit 1896: $1-51$

(Received March 30, 2009 / Accepted June 21, 2009) 